\title{
Spatial Delineation of Rice Yield and Production by the Combination of Rice Crop Modelling and Remote Sensing: A Case Study in Soc Trang Province, Vietnam
}

\author{
Vo Quang Minha, ${ }^{\mathrm{a}}$, Truong Chi Quang ${ }^{\mathrm{a}}$, Thai Thanh $\mathrm{Du}^{\mathrm{a}}$, Tran Thi Hien ${ }^{\mathrm{b}}$ \\ ${ }^{a}$ Department of Land Resources, College of Environment and Natural Resources, Can Tho University, Can Tho city, 900000, Vietnam \\ ${ }^{b}$ Department of Environment and Natural Resources, Ben Tre Province, 930000, Vietnam
}

Corresponding author: ${ }^{*}$ vqminh@ctu.edu.vn

\begin{abstract}
Vietnam's economy mainly depends on the growth of agricultural production. The forecasting yields to consolidate information to assure food security, monitoring, and mapping rice accurately are essential. The study is aimed to (i) delineate the rice distribution status; (ii) simulate the rice yield by using the AQUACROP model; (iii) integrate maps and rice yield to delineate the rice production extent in Soc Trang province. The method involves combining MODIS remote sensing data (MOD13Q1, MOD13A1 at 250m resolution, eight-day intervals) with the AQUACROP rice yield prediction results at 9 study sites within the area. The study delineated three primary rice cropping seasons (Winter-Spring, Spring-Autumn, Autumn-Summer), separated into eight specific rice cropping seasons, depending on the date or rice sowing/transplanting and harvesting. Besides, the difference in rice sowing time of the three main rice cropping seasons was identified and delineated. The simulated rice yield always higher observed rice yields at all seasons, from 8.65 to $22.20 \%$ in the Winter-Spring season, 5 to $28.6 \%$ in Spring-Summer season, and -1 to $49 \%$ in Summer-Autumn. The results were validated by comparing with the government statistical results, which was a very close correlation. The results suggested that we can use the MODIS satellite image for delineating rice cropping status. The rice yield and production can be simulated and delineated by the combination with the rice crop model.
\end{abstract}

Keywords-AquaCrop; rice yields; MODIS; remote sensing.

Manuscript received 26 Mar. 2020; revised 29 Sep. 2020; accepted 15 Feb. 2021. Date of publication 30 Jun. 2021. IJASEIT is licensed under a Creative Commons Attribution-Share Alike 4.0 International License.

\section{INTRODUCTION}

Among crops, rice is the most important for approximately $50 \%$ population of the World [1], [2]. However, the world's rice production growth rate has slowed down during recent years [3]. Vietnam is one of the largest rice exporters, in which, Mekong Delta River (MRD) and Red Delta River (RDR) occupy $95 \%$ of the annual rice exports [4]. Therefore, the rice output forecast is useful in ensuring domestic demand and serving export demand. Especially in the current situation, the rice area has been decreasing. Soc Trang is one of the provinces in the MRD that is affected by climate change [5]. The ability to estimate rice production before the harvesting date is significant for national and provincial planning and decision-making regarding food security and economic planning [6]. Today, the use of remote sensing techniques combined with Geographic Information System (GIS) and statistical methods, spatial interpolation, has been applied to study the spatial distribution characteristic in many countries around the World [7].

The AquaCrop model was developed in 2009, and it has been used worldwide in different agro-ecological conditions. AquaCrop is a crop water productivity model developed by FAO to improve water productivity in rainfed and irrigated fields. It simulates yield response to water of herbaceous crops and is particularly suited to address conditions where water is a key limiting factor in crop production [8]. The AquaCrop model is a good tool to simulate various rice genotypes' behavior, especially improved ones, for management practices established upon seedling age variability [9]. Therefore, the study mainly uses the MODIS satellite images and GIS to delineate the time of sowing/transplanting and then combined with the AquaCrop model to predict and delineate the rice yield in Soc Trang province of Vietnam. 


\section{MATERIALS AND METHODS}

\section{A. The Study Area}

The study conducted in Soc Trang province (105 $34^{\prime} 16^{\prime \prime}$ E - $106^{0} 17^{\prime} 50^{\prime \prime}$ E, $\left.9^{0} 14^{\prime} 20^{\prime \prime} \mathrm{N}-9^{0} 55^{\prime} 30^{\prime \prime} \mathrm{N}\right)$, belongs to the coastal area (Fig. 1). It closes to the Hau River. The total area is $331,176 \mathrm{ha}$, in which agriculture 205,748 ha, forestry $11,356 \mathrm{ha}$, and aquaculture 54,373 ha. The population is $1,312,000$ [10] consists of 11 districts.

\section{B. Data Preparation}

1) Climate, soil, and crop data: AquaCrop requires daily, 10-daily, or monthly temperature (Tmax), minimal temperature (Tmin), rainfall $(\mathrm{P})$, reference evapotranspiration (ETo), and $\mathrm{CO}_{2}$. ETo is estimated from the parameter of Tmin, Tmax, relative humidity, sunshine hour, and wind speed by the ETo calculator program [11] based on the FAO Penman-Monteith method. Physical soil characteristics, such as Texture, Soil moisture content (Permanent Wilting Point PWP, Field Capacity - FC and saturation - Sat, and saturated hydraulic conductivity (Ksat) obtained to run the model. The crop data of rice cultivar collected at the Cuu Long Rice Research Institute in Can Tho city.

2) Remotely sensed data: The images collected from NASA, code MOD09Q1, the spatial resolution of $250 \mathrm{~m}$, and temporal resolution with the eight days from 2012 to 2013. The calculation of NDVI images for rice showing stages and cropping calendar determination. The Red and Near-Infrared bands used for calculation NDVI

TABLE I

THE SPECTRAL BANDS OF MODIS SENSORS USED IN THE CALCUlations OF VEGETATION INDICES

\begin{tabular}{cll}
\hline MODIS band & Wavelength $(\mu m)$ & Resolution $(\mathrm{m})$ \\
\hline 1 & 0.620 to $0.670($ Red $)$ & 250 \\
2 & 0.841 to $0.876($ NIR) & 250 \\
\hline
\end{tabular}

3) Field observation data: Field observation to obtain rice sowing, crop calendar, and rice yield was incorporated to simulate the rice yield model. There are 50 field observation sites to monitor rice sowing, crop calendar, and nine field measurement sites to collect actual yield for accuracy assessment.

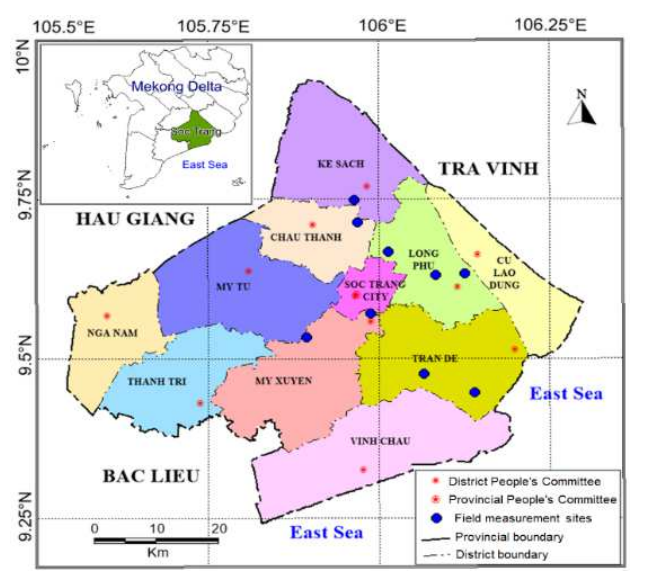

Fig. 1 Study area and field measurement sites

\section{Running AquaCrop Model for Rice Yield Simulate}

AquaCrop-FAO [11] crop-water productivity model to simulate yield response to water. AquaCrop used several parameters and input data to simulate most of the major fields' yield response to water. Before running a simulation, the user specifies the Main menu, the sowing date, and the appropriate environmental, off-season conditions. The collected data from 9 sites used to feed the AquaCrop model to simulate rice yields.

\section{Mapping the Progress of Rice Sowing and Rice Yield}

1) Creating the Normalized Different Vegetation Index (NDVI): The agronomic parameter Normalized Difference Vegetation Index (NDVI) was proposed by [2], which is a numeric indicator of the difference between the wavelengths of the red and near-infrared bands divided by their sum. The NDVI shows an excellent linear correlation with biomass compared to other vegetation indices and expected to be less influenced by changes in atmospheric conditions. Moreover, it is a good indicator of vegetation biomass when the terrain exhibits good vegetation cover [12]. The intermediate evaluation differentiated the characteristics of the materials such as biomass, leaf area index, and photosynthetic capacity seasonally. Those characteristics are relevant and highly dependent on the type of plant cover and weather, physiological characteristics, biochemical, and pests. NDVI averaged in time series data as the essential tool to monitor vegetation status changes, helping understand the impact of weather and climate on the biosphere. NDVI calculated as follows:

$$
N D V I=\frac{(N I R-R)}{(N I R+R)}
$$

2) The relationship between NDVI values and rice growing stages: Each crop with an NDVI value range fluctuates within a certain limit (because on each soil with different characteristics, on fertile lands, the crop that grows well, the NDVI value will reach high and vice versa), in general, the laws of their fluctuations are the same. Based on the results of research by BR Parida et al.[13] in The Gujarat of India proposed NDVI oscillatory intervals for some of the following subjects (table 2): Because the NDVI value of crops changing in a certain situation (each soil type has different properties). The NDVI value changes in the same direction. Based on the research results of [13] in India's Gujarat, the proposed NDVI values of different land use, as shown in Table 2:

TABLE II

NDVI RANGED FOR DIFFERENCE LAND USES

\begin{tabular}{ll}
\hline Range & Land use \\
\hline NDVI $>0.74$ & Forest \\
$0.74>$ NDVI $>0.46$ & Irrigated crops \\
$0.46>$ NDVI $>0.20$ & Rainfed crops \\
$0.20>$ NDVI $>0.15$ & Fallow land \\
$0.15>$ NDVI $>0.05$ & Bare soils \\
$0.05>$ NDVI $>0.001$ & Salt pans \\
NDVI $<-0.001$ & Water \\
\hline
\end{tabular}

(Source: [13])

From the results of processing, combining the actual survey, the NDVI index over time of the whole Mekong Delta, compared with the current rice crop's current status, finds the relationship between the NDVI and the current status of rice teas. Based on the theory that the NDVI number of the 
rice region in the Mekong Delta is low value at the beginning of the crop, gradually increases and reaches the highest at the time of the rice crop at the post-brunch stage, and decreases when the rice plant begins to ripen and the lowest at the end of the crop (Figure 1)

3) Monitoring the progress of rice sowing and delineating the rice cropping calendar: The time series NDVI values of the MRD calculated and delineated, which combined with rice-growing states to find out the relationship between NDVI indexes for rice growing stages [14]. On the basis, low NDVI value at the early stage increased gradually and peaked at the tillering stage and decreased when rice began mature and harvested [15] (Fig 2).

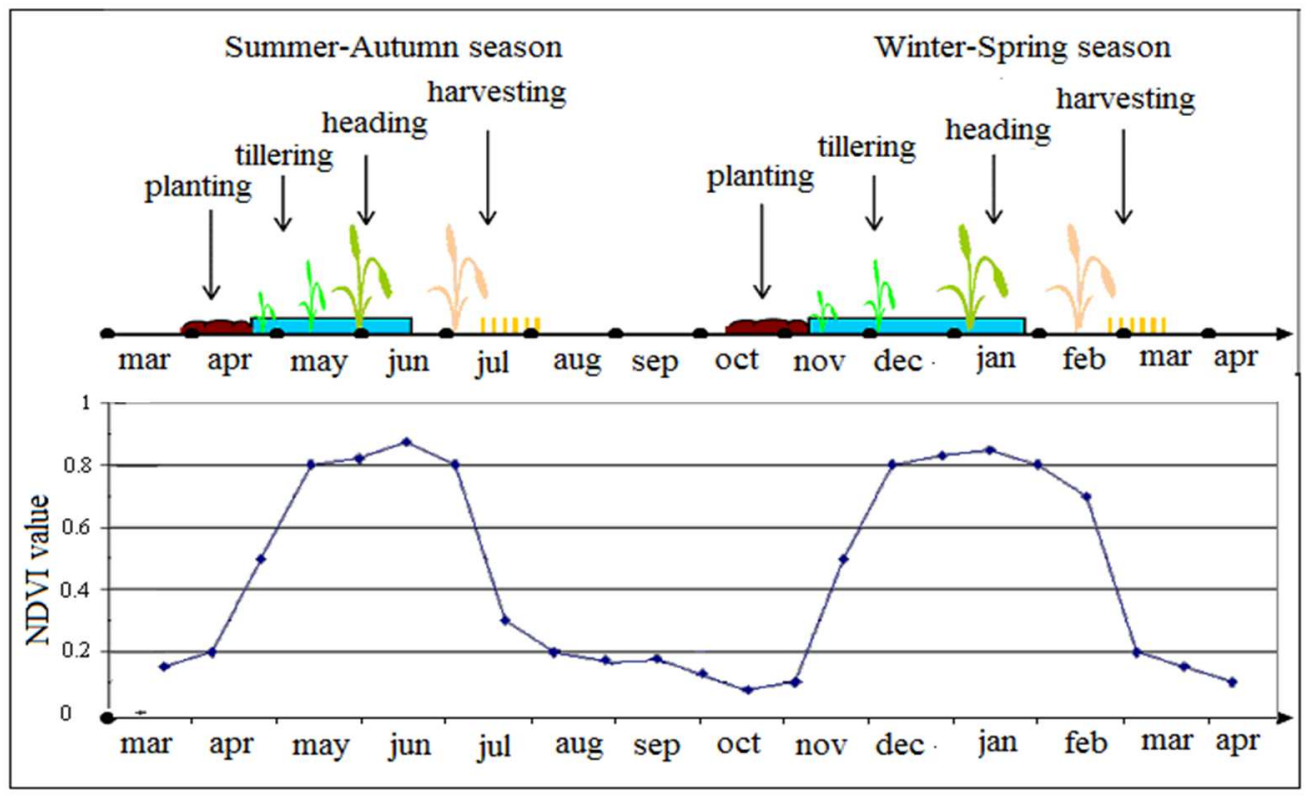

Fig. 2 NDVI change at different rice growing stages in Winter-Spring and Summer-Autumn crops

\section{RESULTS AND DISCUSSION}

\section{A. Climatic and Soil Conditions of the Study Area}

1) Soil Conditions: The soils at nine sites are presented in Table 3. There were four soil groups: group 1 had the highest clay content, including D1, D5, D6, D9 sites; group 4 had the lowest clay content, including D2, D3, D4, D8 sites; group 2 (D7 sites); group 3 (D9 sites).

2) Climatic Conditions: Sets of climatic data were collected from meteorological institutes in Soc Trang province from 2012 to 2013.

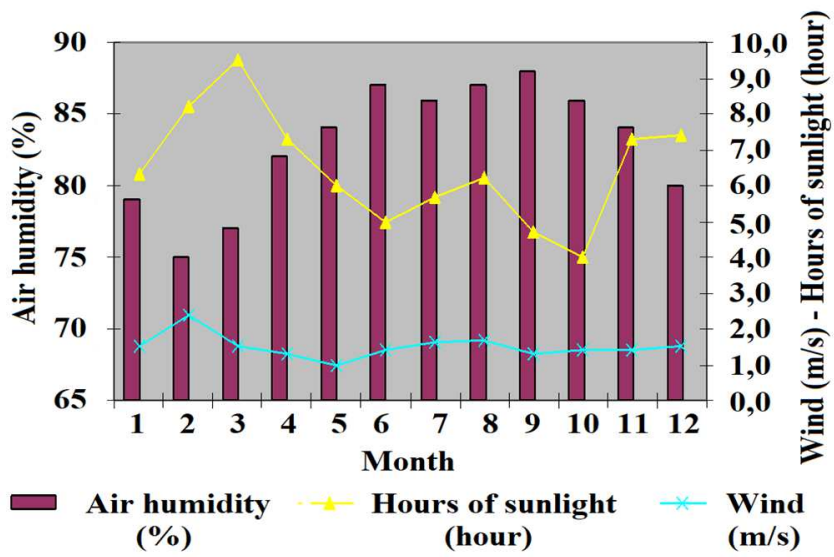

Fig. 3 Monthly average of wind speed and sunlight in 2013 in 2012 of Soc Trang province
Fig. 3 and 4 show the monthly average meteorological of the study area from 2012 to 2013 . The monsoon climate of the tropics characterizes climate regimes in this region. Two distinct seasons are distinguished, including rainy and dry seasons, which occur from May to November and December to April. In general, the pattern is typical throughout the Delta.

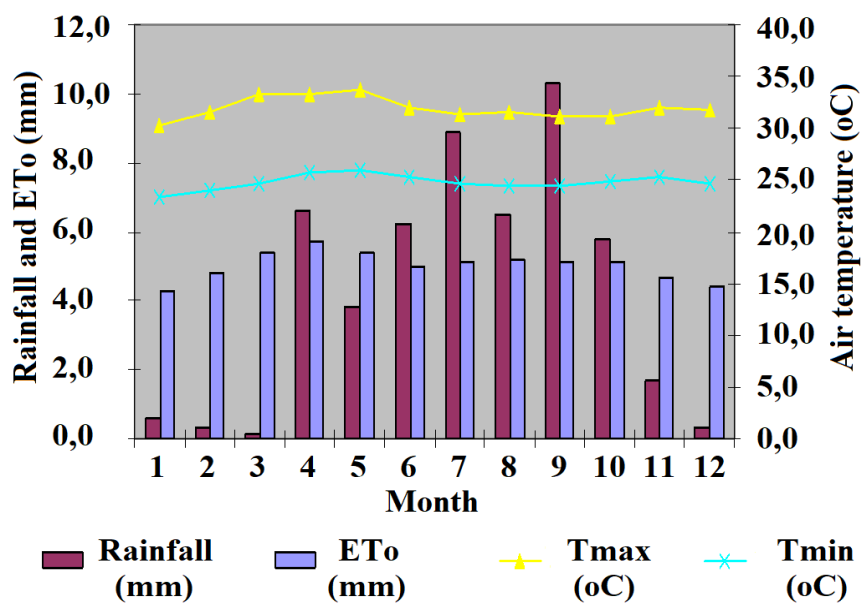

Fig. 4 Monthly average of rainfall, ETo, air temp in 2012 of Soc Trang province

\section{B. Rice Yield Simulation}

Before running a simulation, all input data must be created, including climate, crop, management, and soil, presented above and in Table 4. 
There were two main rice cropping calendars: Triple rice crops (Winter-Spring, Summer-Autumn, Spring-Summer, or Autumn-Winter) Double rice crops (Winter-Spring, SummerAutumn). Rice cultivar was OM 6976, OM 2517, OM 4900, ST5. These are the short growth duration varieties (90-120 days) in three seasons.
The result in Table 5 showing that the simulated and observed rice yields at different sites, but rice yield at all seasons always higher than the observed rice yield from -8.65 to $22.20 \%$ in the Winter-Spring season, 5 to $28.6 \%$ in SpringSummer season, and -1 to $49 \%$ in Summer-Autumn. Since the differences changing site to site due to the differences in soil, pest, cultivation techniques.

TABLE III

PHySICAL SOIL CHARACTERICSTICS AT 9 SITES

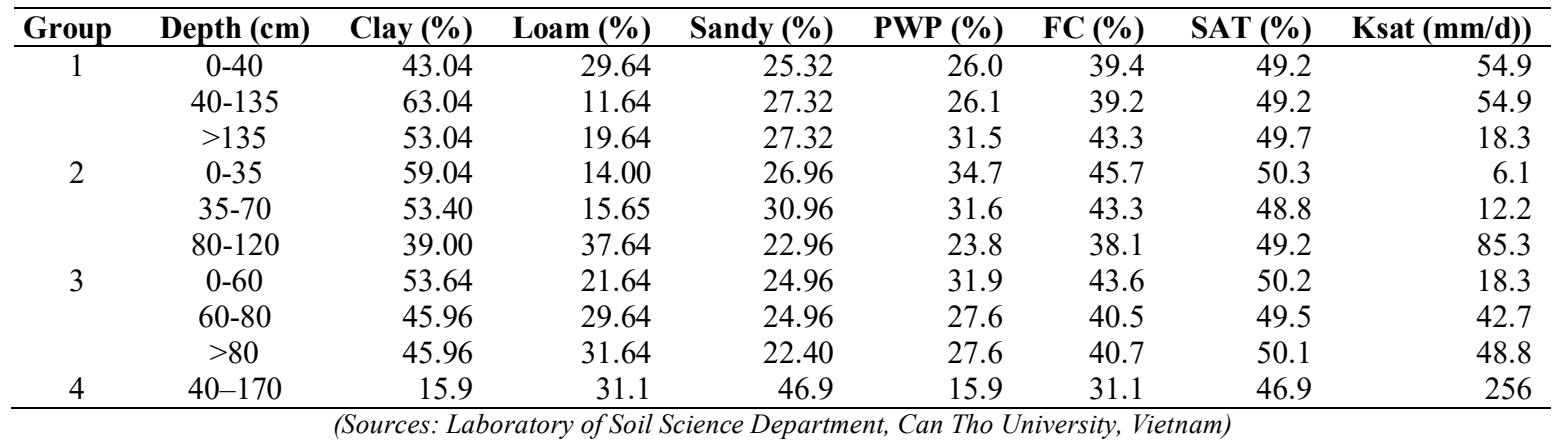

TABLE IV

CHARACTERISTICS OF RICE SEED CULTIVAR

\begin{tabular}{|c|c|c|c|c|}
\hline \multirow[t]{2}{*}{ Parameters } & \multirow[t]{2}{*}{ Unit } & \multicolumn{3}{|c|}{ Rice varieties } \\
\hline & & OM9585, OM6976, OM8017, M10636 & OM4900, OM108-5 & ST5 \\
\hline Growing cycle & days & $90-95$ & 100 & 120 \\
\hline Plant density & plants $/ \mathrm{m}^{2}$ & 146.7 & 146.7 & 146.7 \\
\hline Recovered transplant & Day after seeding & $3-5$ & $3-5$ & $3-5$ \\
\hline Initial canopy cover & $\%$ & 3.22 & 3.22 & 4.0 \\
\hline Maximum canopy & Day after seeding & $40-45$ & $45-50$ & $70-75$ \\
\hline Flowering & Day after seeding & 65 & 70 & 85 \\
\hline Duration of flowering & days & $4-5$ & $4-5$ & $4-5$ \\
\hline Senescence & Day after seeding & 70 & 77 & 90 \\
\hline Maturity & Day after seeding & $90-95$ & $95-100$ & $115-120$ \\
\hline Canopy expansion & $\%$ & 17.3 & 22.3 & 25.3 \\
\hline Maximum canopy cover & $\%$ & 91 & 95 & 105 \\
\hline Canopy decline & $\%$ & 8.9 & 14 & 18.9 \\
\hline Crop water productivity & $\mathrm{g} / \mathrm{m}^{2}$ & 19 & 19 & 19 \\
\hline Harvest Index (HI) & $\%$ & 0.47 & 0.47 & 0.47 \\
\hline Soil water depletion fraction & $\mathrm{P}$ & 0.2 & 0.2 & 0.2 \\
\hline
\end{tabular}

TABLE V

COMPARISON OF SIMULATED WITH OBSERVED YIELDS

\begin{tabular}{|c|c|c|c|c|c|c|c|c|c|}
\hline \multirow[t]{3}{*}{ Site } & \multicolumn{9}{|c|}{ Yield $\left(\mathrm{t} \mathrm{ha}^{-1}\right)$} \\
\hline & \multicolumn{3}{|c|}{ Winter-Spring } & \multicolumn{3}{|c|}{ Spring Summer } & \multicolumn{3}{|c|}{ Summer-Autumn } \\
\hline & Simu & Obs & $\operatorname{diff}(\%)$ & Simu & Obs & $\operatorname{diff}(\%)$ & Simu & Obs & $\operatorname{diff}(\%)$ \\
\hline 1 & 6.4 & 6.5 & -1.26 & 4.5 & 4.2 & 7.67 & 6.3 & 5.0 & 25.44 \\
\hline 2 & 6.0 & 5.0 & 21.05 & 4.1 & 3.2 & 28.65 & 6.8 & 5.6 & 20.84 \\
\hline 3 & 6.1 & 5.0 & 21.77 & 6.2 & 5.4 & 15.25 & 5.8 & 5.4 & 7.53 \\
\hline 4 & 4.6 & 3.8 & 22.20 & - & - & - & 4.5 & 3.5 & 29.13 \\
\hline 5 & 6.2 & 5.5 & 12.41 & - & - & - & 6.7 & 5.3 & 25.55 \\
\hline 6 & 5.8 & 6.4 & -8.65 & 4.8 & 2.1 & 19.57 & 6.3 & 5.8 & 9.09 \\
\hline 7 & 7.1 & 6.0 & 17.53 & 6.1 & 5.7 & 5.81 & 6.1 & 4.7 & 27.82 \\
\hline 8 & 8.1 & 7.8 & 4.59 & - & - & - & 7.1 & 7.2 & -1.35 \\
\hline 9 & 7.1. & 6.6 & 7.11 & - & - & - & 6.2 & 4.1 & 49.03 \\
\hline
\end{tabular}

\section{Time of Rice Sowing}

1) Delineation of Rice Sowing Extend: Based on the relationship between NDVI values with the rice cropping stages over time interpreted from MODIS satellite images, determine each cropping season date's starting and ending.
These results can assist the government in developing the major rice cropping calendars homogeneously for all of the areas to avoid the effect of pests and diseases. Otherwise, the field management for using water, fertilizers, herbicide, and pesticides is easy and effective [16], [17]. The distribution of rice cropping season and date of starting/ending of rice 
sowing/transplanting of each rice crop are showed in Fig 5, 6, 7,8 .

The time of the rice sowing date was changing at a different district. Depending on the flooding season, the rice field receives the water from the rivers to start the new season and leach out the toxicity from saline intrusion and acidic soils.

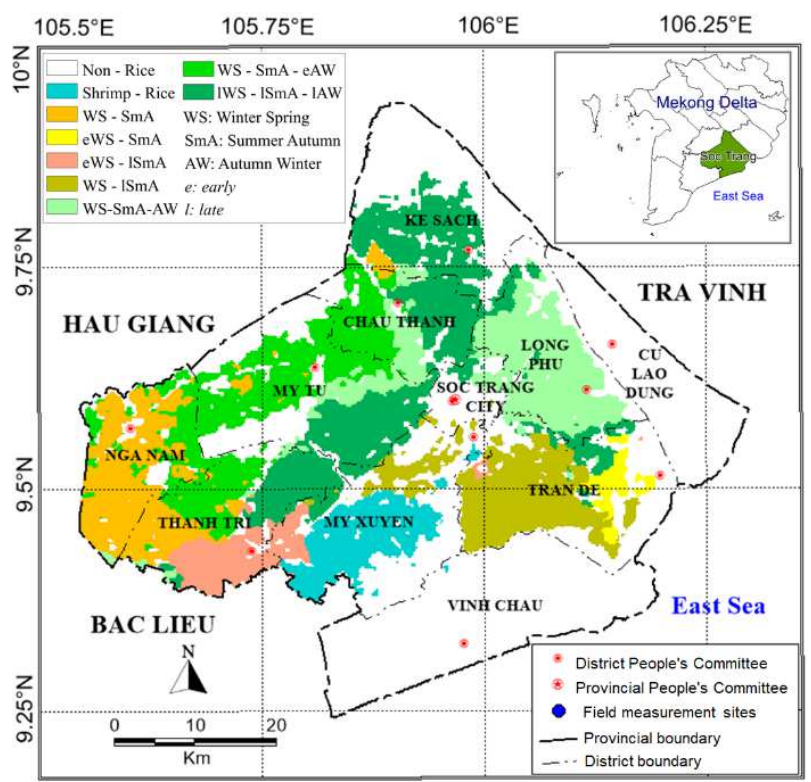

Fig. 5 Rice cropping seasons (2012-2013) map in Soc Trang province
The situation was the same explanation for those fields within the district.

By estimating the starting/ending date of rice sowing for each rice cropping season, the number of rice cropping seasons in different districts identified. It used to predict the district's total rice cultivation area, combining with the expected yield to calculate the rice production.

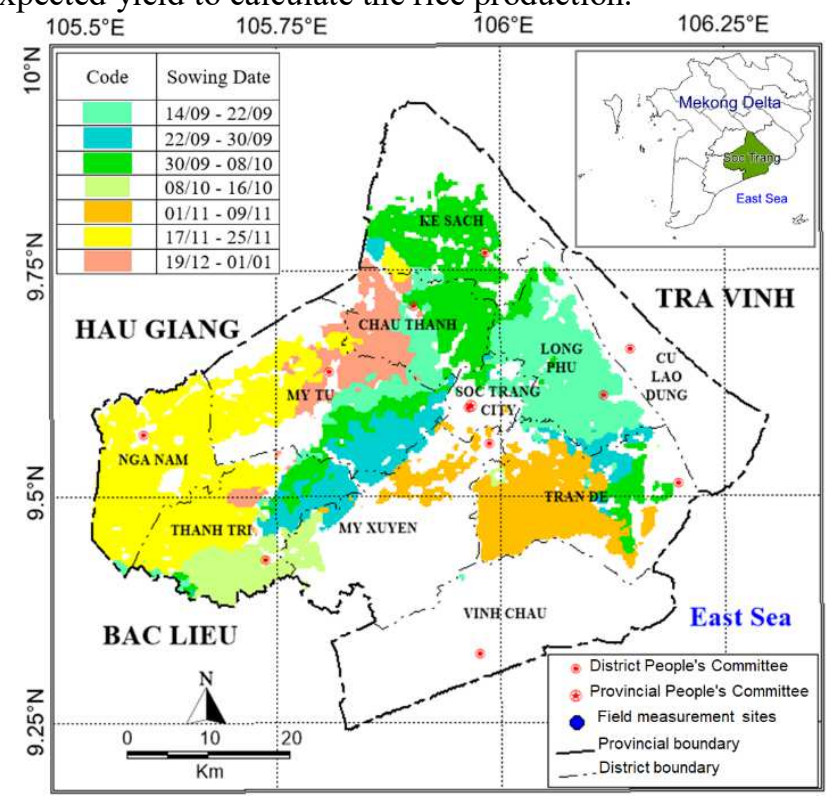

Fig. 6 Rice sowing/transplanting date map in Winter Spring

TABLE VI

LEGEND OF Rice SOWING/TranSPLANTING DATE MAP IN WINTER-SPRING CROPPING SEASONS

\begin{tabular}{|c|c|c|c|c|c|c|c|c|c|c|c|c|}
\hline Code & Sowing Date & $\begin{array}{c}\text { Total } \\
\text { area (ha) }\end{array}$ & $\begin{array}{c}\text { Soc Trang } \\
\text { city }\end{array}$ & Ke Sach & Long Phu & Tran De & $\begin{array}{l}\text { Chau } \\
\text { Thanh }\end{array}$ & $\begin{array}{c}\text { My } \\
\text { Xuyen }\end{array}$ & My Tu & Thanh Tri & $\begin{array}{l}\text { Vinh } \\
\text { Chau }\end{array}$ & Nga Nam \\
\hline & $14 / 09-22 / 09$ & $30,828.6$ & $1,307.7$ & 427.5 & $17,115.6$ & 859.0 & $3,451.4$ & $12,701.9$ & $3,149.9$ & 592.3 & 53.9 & 169.5 \\
\hline & $22 / 09-30 / 09$ & $16,622.1$ & 285.2 & 717.1 & 842.2 & $2,592.2$ & 34.8 & $2,069.5$ & $6,197.6$ & $3,883.5$ & 0.0 & 0.0 \\
\hline & $30 / 09-08 / 10$ & $29,419.7$ & 596.5 & $11,604.6$ & $1,757.5$ & $2,975.7$ & $6,693.3$ & 27.0 & $3,301.7$ & $2,458.1$ & 5.4 & 0.0 \\
\hline & $08 / 10-16 / 10$ & $9,592.3$ & 35.3 & 5.4 & 2.4 & 367.1 & 0.0 & $2,204.9$ & 0.0 & $6,977.2$ & 0.0 & 0.0 \\
\hline & $01 / 11-09 / 11$ & $21,376.1$ & 342.8 & 0.0 & 14.0 & $17,135.8$ & 0.0 & $3,837.6$ & 53.8 & 1.0 & 9.1 & 0.0 \\
\hline & $17 / 11-25 / 11$ & $41,958.9$ & 0.0 & 661.7 & 0.0 & 5.4 & 547.0 & 0.0 & $9,348.0$ & $10,698.1$ & 0.0 & $20,698.7$ \\
\hline & $19 / 12-01 / 01$ & $26,454.8$ & 596.5 & $11,604.7$ & $1,757,55$ & 10.8 & $6,693.4$ & 27.0 & $3,301.7$ & $2,458.1$ & 5.4 & 0.0 \\
\hline
\end{tabular}

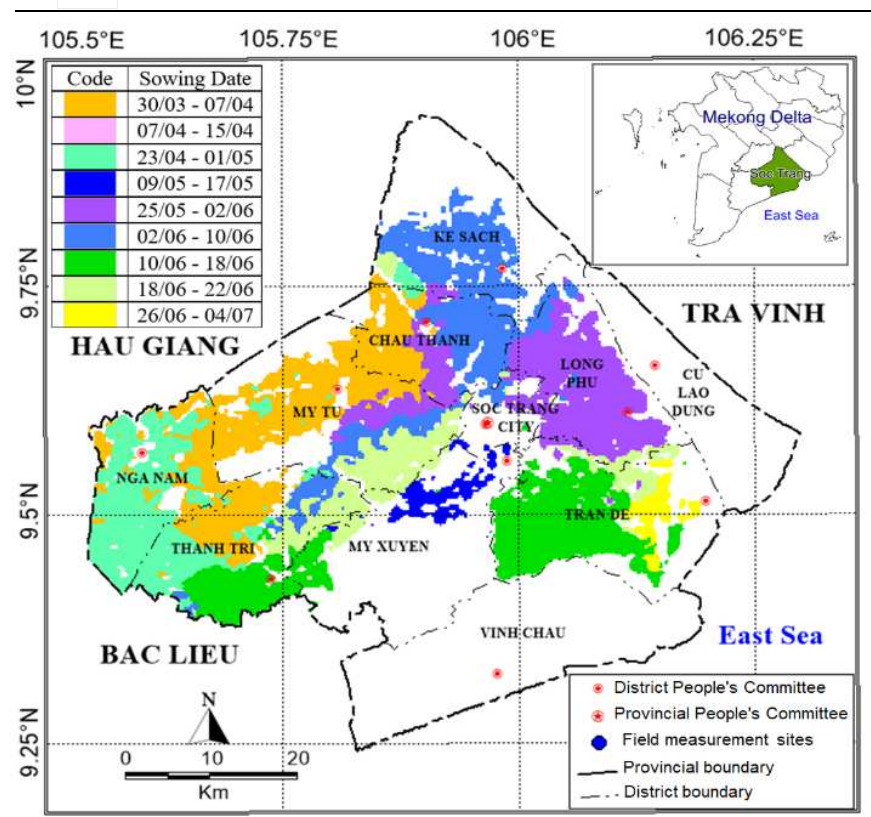

Fig. 7 Rice sowing/transplanting date map in Summer-Autumn

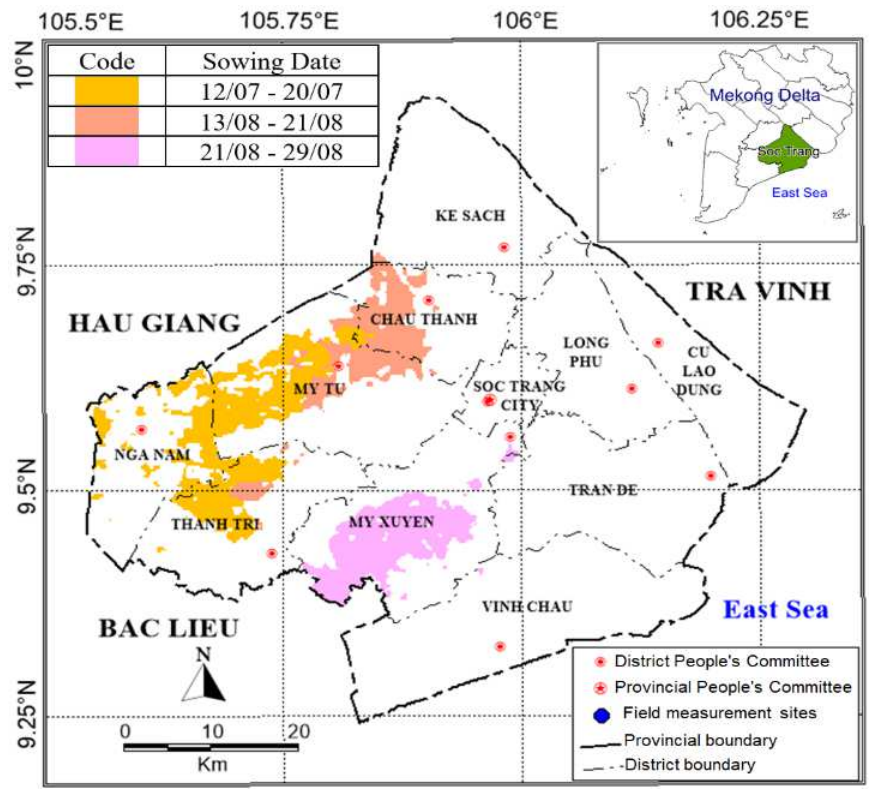

Fig. 8 Rice sowing/transplanting date map in Autumn Winter 
TABLE VII

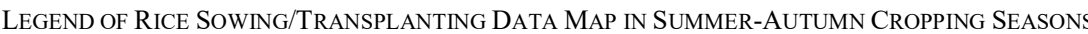

\begin{tabular}{|c|c|c|c|c|c|c|c|c|c|c|c|c|}
\hline Code & Sowing Date & $\begin{array}{c}\text { Total } \\
\text { area (ha) }\end{array}$ & $\begin{array}{c}\text { Soc Trang } \\
\text { city }\end{array}$ & Ke Sach & Long Phu & Tran De & $\begin{array}{l}\text { Chau } \\
\text { Thanh }\end{array}$ & $\begin{array}{c}\text { My } \\
\text { Xuyen }\end{array}$ & My Tu & Thanh Tri & $\begin{array}{l}\text { Vinh } \\
\text { Chau }\end{array}$ & Nga Nam \\
\hline & $30 / 03-07 / 04$ & $20,733.0$ & 0.0 & 0.0 & 0.0 & 0.0 & 279.0 & 0.0 & $9,201.4$ & $5,537.5$ & 0.0 & $5,706.0$ \\
\hline & $07 / 04-15 / 04$ & $12,337.8$ & 0.0 & 149.6 & 0.0 & 0.0 & $6,031.5$ & 0.0 & $5,072.9$ & $1,083.8$ & 0.0 & 0.0 \\
\hline & $23 / 04-01 / 05$ & $23,148.7$ & 0.0 & 703.7 & 0.0 & 0.0 & 229.1 & 0.0 & 702.2 & $5,990.8$ & 0.0 & $15,522.9$ \\
\hline & $09 / 05-17 / 05$ & $3,930.4$ & 185.4 & 0.0 & $17,922.2$ & 0.0 & 0.0 & $3,709.2$ & 35.8 & 0.0 & 0.0 & 0.0 \\
\hline & $25 / 05-02 / 06$ & $27,020.4$ & $1,435.6$ & 409.8 & $1,762.8$ & 739.9 & $3,503.8$ & 0.0 & $3,009.2$ & 0.0 & 0.0 & 0.0 \\
\hline & $02 / 06-10 / 06$ & $27,429.0$ & 644.2 & $12,183.6$ & 41.8 & 0.0 & $7,029.4$ & 0.0 & $3,415.7$ & $2,393.3$ & 0.0 & 0.0 \\
\hline & $10 / 06-18 / 06$ & $28,115.2$ & 53.9 & 0.0 & 777.9 & $18,538.9$ & 0.0 & $2,381.9$ & 0.0 & $7,069.7$ & 29.0 & 0.0 \\
\hline & $18 / 06-22 / 06$ & $15,808.1$ & 195.7 & 587.7 & 0.0 & $1,831.7$ & 0.8 & $2,108.7$ & $6,308.7$ & $3,997.0$ & 0.0 & 0.0 \\
\hline & $26 / 06-04 / 07$ & $3,299.2$ & 0.0 & 0.0 & 0.0 & $\begin{array}{c}3,299.2 \\
\text { Non - R }\end{array}$ & 0.0 & 0.0 & 0.0 & 0.0 & 0.0 & 0.0 \\
\hline
\end{tabular}

TABLE VIII

LEGEND of Rice Sowing/TranPlaning Data MAP In AUMTUM-Winter CROPPING SEASON

\begin{tabular}{|c|c|c|c|c|c|c|c|c|c|c|c|c|}
\hline Code & Sowing Date & $\begin{array}{c}\text { Total } \\
\text { area (ha) }\end{array}$ & $\begin{array}{c}\text { Soc Trang } \\
\text { city }\end{array}$ & Ke Sach & Long Phu & Tran De & $\begin{array}{l}\text { Chau } \\
\text { Thanh }\end{array}$ & $\begin{array}{c}\text { My } \\
\text { Xuyen }\end{array}$ & My Tu & Thanh Tri & $\begin{array}{l}\text { Vinh } \\
\text { Chau }\end{array}$ & Nga Nam \\
\hline & $12 / 07-20 / 07$ & $9,666.8$ & 5.4 & 0.0 & 0.0 & 291.1 & 0.0 & $2,300.6$ & 0.0 & $7,069.7$ & 0.0 & 0.0 \\
\hline & $13 / 08-21 / 08$ & $12,337.8$ & 0.0 & 149.6 & 0.0 & 0.0 & $6,031.5$ & 0.0 & $5,072.9$ & $1,083.8$ & 0.0 & 0.0 \\
\hline & $21 / 08-29 / 08$ & $13,663.7$ & 0.0 & 0.0 & 0.0 & 121.4 & 0.0 & $13,493.3$ & 0.0 & 0.5 & 48.5 & 0.0 \\
\hline & \multicolumn{12}{|c|}{ Non-Rice } \\
\hline
\end{tabular}

2) Accuracy Assessment: The result compared with the statistical parameters for 2012 and 2013 years (official collected from the Department of Statistical office of the province) presented in Table 9.

TABLE IX

COMPARISON OF PREDICTED WITH OBSERVED AREA USING STATISTICAL PARAMETER IN SOCTRANG PROVINCE [18], [19]

\begin{tabular}{ccccr}
\hline & $\begin{array}{c}\text { Statistics } \\
\text { (ha) }\end{array}$ & $\begin{array}{c}\text { Predicted } \\
\text { (ha) }\end{array}$ & $\begin{array}{c}\text { Difference } \\
\text { (ha) }\end{array}$ & \multicolumn{1}{c}{$\begin{array}{c}\text { Diff } \\
(\%)\end{array}$} \\
\hline Winter-Spring & 138,842 & 176,253 & 37,411 & 21 \\
Summer & 199,924 & 161,822 & $-38,102$ & -24 \\
Autumn & & & & \\
Autumn & 31,487 & 35,668 & 4,181 & 12 \\
$\quad$ Winter & 370,253 & 373,743 & 3,490 & 9 \\
Total & & & & \\
\hline
\end{tabular}

The difference comparison between statistics and interpretation data shows a close correlation between the two results data. The predicted area always higher than the statistic data. However, during the Winter-Spring season, the difference was higher than the Autumn-Winter season; this means the expected yield was higher than the statistical result. Due to this season, several rice fields were harvested, but the rice leaflets of some alive rice remained in the field. Otherwise, at the end of the rainy and the start of dry seasons with saline water intrusion, several crops such as corn, grass, sugarcane, etc., impaired the satellite image interpretation results.

\section{Delineation of Rice Yield and Production}

The map of time of rice sowing combined with the result of rice yield simulated to create a rice yield map. Fig 9, 10, and 11 showing that the different colors mean different rice yields. The concentration of higher yield on the alluvial soil, which receives enough water for irrigation. While the lower rice yield was mostly on acid sulfate soils and saline water affected from the sea. The white color was non-rice, such as urban, fruit crops, mangrove, sugarcane, pineapple, etc.

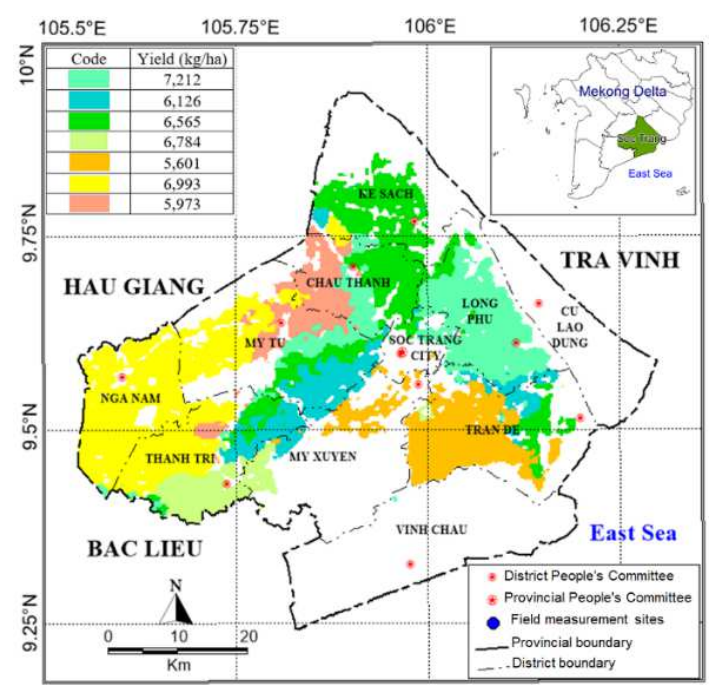

Fig. 9 Rice yield map of Winter-Spring in Soc Trang province

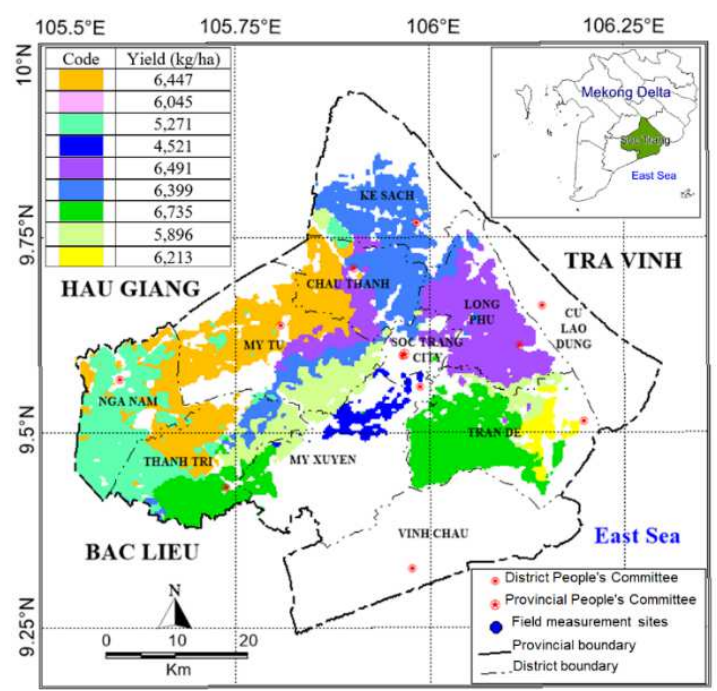

Fig. 10 Rice yield map of Summer Autumn in Soc Trang province 


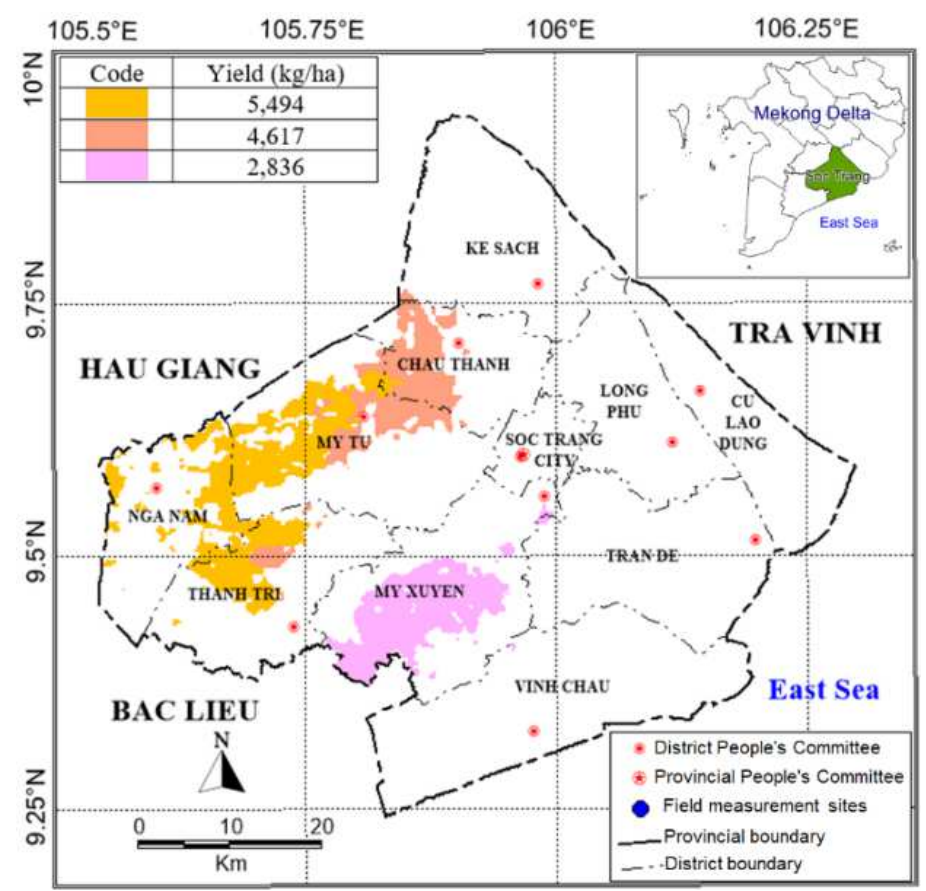

Fig. 11 Rice yield map of Autumn Winter at different districts in Soc Trang province

The rice production was calculated in ton/ha by multiplying the rice yield in ton/ha with rice cropping season in ha. The results show in Table 10. The difference between the estimated rice yield and observed is inevitable. Many causes lead to this discrepancy, such as acid sulfate soils with high toxicity, low $\mathrm{pH}$, and saline or soil fertility levels, which limited the rice-growing and then rice yield. The simulated rice yield, affected by pests and diseases, was not included in the model. Table 11 showing the difference between estimated or predicted from the model with statistical rice production from government varies by season and area.

TABLE X

Comparison of The Estimated with Statistical Rice Production OF Districts In Soctrang Province in 2013 [19]

\begin{tabular}{|c|c|c|c|c|c|c|c|c|c|}
\hline \multirow[t]{3}{*}{ District } & \multicolumn{9}{|c|}{ Rice production (ton) } \\
\hline & \multicolumn{3}{|c|}{ Winter-Spring (2012-2013) } & \multicolumn{3}{|c|}{ Spring-Summer/Summer Autumn 2013} & \multicolumn{3}{|c|}{ Autumn Winter 2013} \\
\hline & Est & Obs & $\operatorname{dif}(\%)$ & Est & Obs & $\operatorname{dif}(\%)$ & Est & Obs & $\operatorname{dif}(\%)$ \\
\hline Soc Trang & $20,595.8$ & 20,998 & 1.9 & $15,795.7$ & 29,039 & 45.6 & 31.7 & - & - \\
\hline Ke Sach & $156,439.2$ & 72,762 & 115.0 & $88,701.5$ & 127,939 & 30.6 & 690.5 & - & - \\
\hline Long Phu & $148,993.3$ & 102,876 & 44.8 & $132,481.5$ & 160,399 & 17.4 & - & - & - \\
\hline Tran De & $140,100.7$ & 142,767 & -1.8 & $160,959.1$ & 140,113 & -14.8 & $2,060.2$ & - & - \\
\hline Chau thanh & $111,867.5$ & 94,856 & 17.9 & $107,195.0$ & 171,303 & 37.4 & $27,847.4$ & 15,028 & -85.3 \\
\hline My Xuyen & $57,401,9$ & 48,588 & 18.1 & $45,244.2$ & 46,051 & 1.7 & $51,826.4$ & 58,362 & 11.2 \\
\hline Thanh Tri & $180,732.6$ & 151,613 & 19.2 & $160,325.3$ & 202,484 & 20.8 & $46,674.4$ & 14,009 & -233.1 \\
\hline Vinh Chau & 502.1 & - & - & 194.9 & - & - & 137.6 & 500 & 72.4 \\
\hline Nga Nam & $145,952.4$ & 133,157 & 9.6 & $118,607.9$ & 96,171 & -23.3 & - & 14,541 & 100.0 \\
\hline
\end{tabular}

TABLE XI

COMPARISON OF THE ESTIMATED WITH STATISTICAL Rice PRODUCTION IN SOCTRANG PROVINCE

\begin{tabular}{lrrr}
\hline & $\begin{array}{c}\text { Estimated } \\
\text { (ton) }\end{array}$ & \multicolumn{1}{c}{$\begin{array}{c}\text { Observed } \\
\text { (ton) }\end{array}$} & $\begin{array}{c}\text { Differences } \\
\text { (\%) }\end{array}$ \\
\hline Winter-Spring 2012-2013 & $1,072,318$ & 909,750 & 17.9 \\
Summer Autumn 2013 & $1,002,000$ & $1,128,220$ & 11.2 \\
Autumn Winter 2013 & 151,968 & 158,583 & 4.2 \\
Total & $2,226,285$ & $2,196,553$ & 1.4 \\
\hline
\end{tabular}

\section{CONCLUSION}

Monitoring the date of starting rice sowing based on the temporal variation of MODIS - NDVI satellite images are very effective and useful to determine the current rice evolution states, rice sowing stages, rice cropping calendar. This assists the government in understanding the near realtime and its distribution on the field to develop the strategies for rice sowing/transplanting homogeneously for better rice management and rice yield. However, to increase the accuracy of predicted data at the district level, it should combine high spatial resolution satellite images to simulate the rice yields. It has been successful when combining MODIS satellite images as rice sowing stages maps to delineate and predict the rice yield and production.

As a result, simulated yields are usually higher than actual rice yield, and accuracy varies by season and area. The model does not consider the limitation of fertility, weeds, and pests for rice yield and production during the running process. These factors can affect the rice yield, which causes the deviation of simulated rice yield.

\section{ACKNOWLEDGMENT}

This study is funded in part by the Can Tho University Improvement Project VN14-P6 (supported by a Japanese 
ODA loan), and Ministry of Education support for the annual study, and VLIR (CTU-Belgium) projects, and Department of Science and Technology of the province.

\section{REFERENCES}

[1] K. Clauss, M. Ottinger, P. Leinenkugel, and C. Kuenzer, "Estimating rice production in the Mekong Delta, Vietnam, utilizing time series of Sentinel-1 SAR data," Int. J. Appl. Earth Obs. Geoinformation, vol. 73, pp. 574-585, Dec. 2018, doi: 10.1016/j.jag.2018.07.022.

[2] M. Mosleh, Q. Hassan, and E. Chowdhury, "Application of Remote Sensors in Mapping Rice Area and Forecasting Its Production: A Review," Sensors, vol. 15, no. 1, pp. 769-791, Jan. 2015, doi: 10.3390/s150100769.

[3] C. Kontgis, A. Schneider, and M. Ozdogan, "Mapping rice paddy extent and intensification in the Vietnamese Mekong River Delta with dense time stacks of Landsat data," Remote Sens. Environ., vol. 169, pp. 255-269, Nov. 2015, doi: 10.1016/j.rse.2015.08.004.

[4] Government of Vietnam, "Resolution on sustainable and climateresilient development of the Mekong Delta." 2017.

[5] H. Arai et al., "Function of the methanogenic community in mangrove soils as influenced by the chemical properties of the hydrosphere," Soil Sci. Plant Nutr., vol. 62, no. 2, pp. 150-163, Mar. 2016, doi: 10.1080/00380768.2016.1165598.

[6] T. D. Setiyono et al., "Rice yield estimation using synthetic aperture radar (SAR) and the ORYZA crop growth model: development and application of the system in South and South-east Asian countries," Int. J. Remote Sens., vol. 40, no. 21, pp. 8093-8124, Nov. 2019, doi: 10.1080/01431161.2018.1547457

[7] P. A. Burrough, R. McDonnell, and C. D. Lloyd, Principles of geographical information systems, Third edition. Oxford; New York: Oxford University Press, 2015.

[8] P. Mejias and M. Piraux, "AquaCrop, the crop water productivity model," FAO, 2017.
[9] R. S. Raoufi, S. Soufizadeh, B. A. Larijani, M. AghaAlikhani, and J. Kambouzia, "Simulation of growth and yield of various irrigated rice (Oryza sativa L.) genotypes by AquaCrop under different seedling ages," Nat. Resour. Model., vol. 31, no. 2, p. e12162, 2018, doi: https://doi.org/10.1111/nrm.12162.

[10] Soc Trang Statistic Office, Statistic year book of Soc Trang province 2018. Statistical publishing house, Vietnam, 2018.

[11] D. Raes, P. Steduto, C. Hsiao, and E. Fereres, "AquaCrop, version $3.1+$, reference manual." FAO, Rome, 2011.

[12] J. B. Campbell and R. H. Wynne, Introduction to remote sensing, 5th ed. New York: Guilford Press, 2011.

[13] B. R. Parida, B. Oinam, N. R. Patel, N. Sharma, R. Kandwal, and M. K. Hazarika, "Land surface temperature variation in relation to vegetation type using MODIS satellite data in Gujarat state of India," Int. J. Remote Sens., vol. 29, no. 14, pp. 4219-4235, Jul. 2008, doi: 10.1080/01431160701871096.

[14] N.-T. Son, C.-F. Chen, C.-R. Chen, H.-N. Duc, and L.-Y. Chang, “A Phenology-Based Classification of Time-Series MODIS Data for Rice Crop Monitoring in Mekong Delta, Vietnam," Remote Sens., vol. 6, no. 1, Art. no. 1, Jan. 2014, doi: 10.3390/rs6010135.

[15] Tran Thi Hien and Vo Quang Minh, "Modis satellite images in rice sowing date monitoring in the Mekong Delta," Vietnam Agric. Publ. House, pp. 85-93, 2010.

[16] K. A. Osman, A. M. Mustafa, Y. M. A. Elsheikh, and A. E. Idris, "Influence of different sowing dates on growth and yield of direct seeded rice (Oryza sativa L.) in semi-arid zone (Sudan)," IJAAR, vol. 6, no. 6, pp. 38-48, 2015.

[17] Q. Liu, X. Wu, J. Ma, B. Chen, and C. Xin, "Effects of Delaying Transplanting on Agronomic Traits and Grain Yield of Rice under Mechanical Transplantation Pattern," PLOS ONE, vol. 10, no. 4, p. e0123330, Apr. 2015, doi: 10.1371/journal.pone.0123330.

[18] Soc Trang Statistic Office, Statistic year book of Soc Trang province 2012. Statistical publishing house, Vietnam, 2012

[19] Soc Trang Statistic Office, Statistic year book of Soc Trang province 2013. Statistical publishing house, Vietnam, 2013. 